\title{
Collectivism and Organizational Citizenship Behavior
}

\author{
Zhan-Fang Sun \\ No.555, Longyuan Road, East China University of Political Science and Law, Shanghai, China \\ sophiase@126.com
}

Keywords: Collectivism, Organizational citizenship behavior, Individualism.

\begin{abstract}
Present studies on Organizational Citizenship Behavior (OCB) have expanded substantially in contents of society and culture. Collectivism may affect One's Self-Control and self -enhancement. This Paper compared the common points and differences between concepts and dimensions of OCB in the west countries and China, reviewed previous research results and explained how the collectivism cultural effect on OCB in China which as a typical collective cultural country.
\end{abstract}

\section{Definition and Dimensions of OCB}

Smith et al. (1983) and Bateman and Organ (1983) introduced the notion of organizational citizenship behavior (OCB) based on earlier work of Barnard (1938), Katz and Kahn (1977). OCB was defined as extra-role discretionary behavior intended to help others in the organization or to demonstrate conscientiousness in support of the organization. Smith et al. developed a 16-items survey that is used as a self-report instrument or as rating scales. Two factors emerge from factor analysis:(a) Altruism, or helping others, and (b) Generalized Compliance, following the rules and procedures of the organization (Organ, 1988).

Organ (1988) further defined OCB as "individual behavior that is discretionary, not directly or explicitly recognized by the formal reward system, and that in the aggregate promotes the effective functioning of the organization". Organ (1990) outlined three critical components of this definition of OCB:(1) the behavior is not part of employee's job requirement,(2) the behavior is not guaranteed to be rewarded formally, and (3)the behavior, although mundane in nature, contributes to organizational effectiveness when aggregated across people and time.

Organ's conceptualization of OCB promoted researchers to question the boundary between in-role and extra-role behavior and argue the categorization of behavior as in-role or extra-role may vary across job incumbents and change over time (Morrison, 1994; Van Dyne, Graham and Dienesch, 1994). In response, Van Dyne et al. (2004) drew upon political and active citizenship syndrome and defined OCB as "Global behavior at work".

Since then OCB received significant attention in terms of its conceptualization, dimensionality and antecedents. Organ (1990) outlined three critical components of this definition of OCB: (1) the behavior is not part of employee's job requirements, (2) the behavior is not guaranteed to be rewarded formally, and (3) the behavior, although mundane in nature, contributes to organizational effectiveness when aggregated across people and time. OCB reflects individual contributions in the workplace that go beyond role requirements and contractually rewarded job achievements (Organ and Ryan1955).

Based on prior research (Bateman \& organ, 1983; Graham, 1986a; Smith et al., 1983), Organ (1988) specific five dimensions of OCB: (1) Altruism consists of discretionary behaviors which are aimed at helping specific persons with an organizationally relevant task or problem. (2) Conscientiousness, which was originally called Generalized Compliance, refers to employees going beyond minimal requirements in carrying out their assigned tasks. (3) Sportsmanship refers to activities that employees refrain from doing, such as complaining and filing petty grievances. (4) Courtesy includes such actions as giving others advance notice, issuing reminders to others, checking with others before taking action, and passing along information. (5) Civic Virtue is defined as responsible participation in the political life of the organization (Graham, 1986.) Employees engaging in this type of OCB keep themselves informed of matters affecting the organization, attend meetings, contribute to discussions, 
and generally get involved in organizational activities in order to assist and improve the organization. Empirical support for a five-factor structure of OCB has been provided in two studies employing confirmatory factor analysis (Moorman et al., 1991; Podsakoff et al., 1990; Williams et al., 1986).

Some scholars also have utilized a unidimensional or overall OCB measure in their research (e.g., Decktop, Mangel, \& Cirka, 1999). A most recent meta-analysis conducted by Hoffman, Blair, Meriac, and Woehr (2007) suggested that "current operationalizations of OCB are best viewed as indicators of a general OCB factor, there is likely little to be gained through the use of separate dimensional measures as opposed to an overall composite measure" (p.562). A similar conclusion was reached by a previous meta-analysis (LePine, Erez, \& Johnson, 2002).

As stated by LePine, Erez, and Johnson (2002), these behavioral dimensions have yet to be differentiated from one another in the empirical literature even though many scholars have claimed that OCB is composed of conceptually distinct behavioral dimensions. Studies have found that there are approximately 30 forms of citizenship behavior have been developed (Podsakoff, Mackenzie, Paine \& Bachrach, 2000) and generally it can be grouped into seven dimensions known as, (1)helping behavior, (2) sportsmanship, (3) organizational loyalty, (4)organizational compliance, (5) individual initiative, (6) civic virtue, and (7) self development.

\section{Research Streams of OCB}

The majority of the research to date has focused on identifying antecedents of OCB. Job satisfaction (Organ and Ling, 1995; Smith et al., 1983), leader supportiveness (smith et al., 1983), organizational commitment (O'Reily and Chatman, 1986; Williams and Anderson, 1991), Perceived fairness (Farh et al., 1900; Moorman, 1991) and personality (Organ and lingl, 1995; Organ and Konovsky, 1989) have been frequently measured.

Another research stream has examined the relationship between OCB and organizational performance. Organ (1988) claimed that OCB might improve organizational performance by freeing scarce resources and decreasing the amount of resources and organization would need to devote solely to maintenance functions. However, Borman and Motowidlo (1993) argued that the premise for predicting organizational performance from OCB was 'typically logical and conceptual rather than empirical. Yet a number of empirical investigations have indicated that OCB has a positive effect on performance (Allen and Rush, 1998; Lowery and Krilowicz, 1996; Mackenzie, Podsakoff and Fetter, 1991; Mackenzie et al., 1993; Podsakoff et al., 1997; Podsakoff and Mackenzie; Skarlicki and Latham, 1995). Podsakoff and MacKenzie (1997) suggest that OCB may improve performance because they could enhance co-worker or manager productivity; free up resources; help to co-ordinate activities between employees; enhance attraction and retention of employees; reduce work performance variability; and help an organization's ability to adapt to change. Samuel et al. (2007) examined processes linking high-performance human resource practices and productivity and turnover, two indicators of organizational performance, and revealed that Service-oriented organizational citizenship behavior partially mediated the relationships between high-performance human resource practices and both performance indicators.

One of the most promising of OCB is to consider the beneficiaries of these behaviors (Williams and Anderson, 1991). Specifically, research supports a two-factor classification of OCB into behavior that ate interpersonally-focused and directly and intentionally aimed at assisting others (i.e., OCBI, which include behavior such as orienting new employees and assisting a fellow employee with heavy work load), and more organizationally-focused OCB that function as a more impersonal form of citizenship behavior directed at accomplishing organizational goals (i.e., OCBO, Latham and Skarlicki, 1995; Williams and Anderson, 1991).

\section{OCB's Research in China}

In the circumstance of Chinese organizations, Jiing-Lih Farh (Farh) has achieved the most research results of organizational citizenship behavior. As a chairman professor of The Hong Kong 
University of Science and Technology, he is engaged in organizational behavior with his team which includes about 40 members .

Through the research on Taiwan organizational staff, Farh (1997) proposed the five dimensions structure of organizational citizenship behavior about Taiwan staff: Identification with Compare,Altruism toward Colleagues, Conscientiousness, Interpersonal Harmony and Protecting Company Resources.

In 2004, Farh presented the 10 Chinese OCB dimensions, and divided them into two groups: 5 common dimensions and 5 extended dimensions. Common dimensions are Chinese OCB dimensions whose content domains resemble those of the major OCB dimensions which include Taking Initiative, Helping Coworkers, Voice Group, Activity Participation and Promoting Company Image. Extended dimensions are Chinese OCB dimensions whose content domains differ from any of the existing Western OCB dimensions in the literature which include Self-Learning, Social Welfare Participation, Protecting and Saving Company Resources, Keeping the Workplace Clean and Interpersonal Harmony.

Tab. 1 Dimensions of OCB Between Western literature and Chinese

\begin{tabular}{|l|l|}
\hline \multicolumn{1}{|c|}{ Dimensions } & \multicolumn{1}{c|}{ Source } \\
\hline Altruism, General Compliance & Bateman \& Organ, 1983 \\
\hline $\begin{array}{l}\text { Altruism, Conscientiousness, Sportsmanship, Courtesy, } \\
\text { Civic Virtue }\end{array}$ & Organ, 1988 \\
\hline $\begin{array}{l}\text { Interpersonal Helping, Individual Initiative, personal } \\
\text { Industry }\end{array}$ & Graham, 1989 \\
\hline $\begin{array}{l}\text { Organization-directed OCB(OCBO), } \\
\text { Individual-directed OCB(OCBO) }\end{array}$ & Williams \& Anderson, 1991 \\
\hline Obedience, Loyalty, Participation & $\begin{array}{l}\text { Van Dyne,Graham \& Dienesch, } \\
1994\end{array}$ \\
\hline Helping Behavior, Civic Virtue, Sportsmanship & Podsakoff et. al, 1997 \\
\hline $\begin{array}{l}\text { Identification with the company, Altruism to Colleagues, } \\
\text { Conscientiousness, Interpersonal Harmony, Protecting } \\
\text { Company }\end{array}$ & Farh, J. L, Earley \& Lin, 1997 \\
\hline $\begin{array}{l}\text { Taking Initiative, Helping Coworkers, Voice, Participation } \\
\text { in group activities, Promoting and saving company } \\
\text { resource,Keeping workplace clean, Interpersonal harmony }\end{array}$ & Farh, J. L, 2000 \\
\hline $\begin{array}{l}\text { Helping Behavior, Organizational Loyalty, Self } \\
\text { Development }\end{array}$ & Podsakoff, 2000 \\
\hline
\end{tabular}

Furthermore, Farh (2004) proposed a concentric model to classify OCB. In this model, OCB can be classified into four domains based on the focus or context of action: self, group, organization, and society. (1) The self domain includes contributions that in principle could be rendered anonymously, privately, and purely as a matter of one's own volition. Three types of OCB in China: self-training, taking initiative, and keeping the workplace clean fit in this focus. (2) The group domain includes those contributions that cannot be meaningfully or practically divorced from a context of interaction with peers. Interpersonal harmony and helping coworkers both fall into this focus. (3) OCB with an organizational focus includes those contributions that must engage some organizationally relevant attribute, such as corporate resources, governance, workflow, or technology. Here we would locate OCB dimensions such as protecting and saving company resources, voice, and group activity participation. These activities do not relate to specific people, yet they contribute to general organizational effectiveness. (4) The society focus subsumes those contributions that can be enacted only across the boundary of the organization or in its external environment with outside stakeholders. Social welfare participation and protecting company image fit this description. 
Tab. 2 Commons and Differences Between Chinese OCB and Western

\begin{tabular}{|c|c|}
\hline Dimension & Conception \\
\hline Taking Initiative & $\begin{array}{l}\text { Behavior that indicates one's willingness to take on additional } \\
\text { responsibilities such as voluntarily working overtime, performing extra } \\
\text { duties, and sharing useful work-related information. } \\
\text { Similar Western Dimension: Conscientiousness (Smith et al, 1983), } \\
\text { Functional Participation (Van Dyne et al, 1994), Job Dedication (Van } \\
\text { Scotter and Motowidlo, 1996) }\end{array}$ \\
\hline $\begin{array}{r}\text { Helping } \\
\text { Coworkers }\end{array}$ & $\begin{array}{l}\text { Refers to helping colleagues in work-related matters or nonwork } \\
\text { matters } \\
\text { Similar Western Dimension: Altruism (Smith et al, 1983), Helping (Van } \\
\text { Dyne and LePine, 1998), However, helping colleagues in China is broader } \\
\text { in scope than its western counter parts in that it includes helping with } \\
\text { work-related matters as well as non work matters. }\end{array}$ \\
\hline Voice & $\begin{array}{l}\text { Making constructive suggestions or speaking up to prohibit harmful } \\
\text { behavior to the firm. } \\
\text { Similar Western Dimension:Voice (Van Dyne and LePine, 1998). } \\
\text { However, Chinese one is broader, it also includes prohibitive voice } \\
\text { aimed at preventing others from doing harm to the firm. }\end{array}$ \\
\hline $\begin{array}{l}\text { Group Activity } \\
\text { Participation }\end{array}$ & $\begin{array}{l}\text { Refers to participating in activities organized by the firm or by special } \\
\text { groups of employees. } \\
\text { Similar Western Dimension: Civic virtue (Organ, 1988. Podsakoff et al, } \\
\text { 1990) However, the items refer mainly to activities organized by employee } \\
\text { groups, which is quite different from the U.S. literature. }\end{array}$ \\
\hline $\begin{array}{l}\text { Promoting } \\
\text { Company } \\
\text { Image }\end{array}$ & $\begin{array}{l}\text { Agree with the organizational goals and safeguard the organizational } \\
\text { image. } \\
\text { Similar Western Dimension: Loyalty (Van Dyne et al, 1994) }\end{array}$ \\
\hline Self-Learning & Refers to improving one's knowledge or working skills. \\
\hline \begin{tabular}{cc|} 
Social Welfare \\
Participation
\end{tabular} & $\begin{array}{l}\text { Refers to employees' participation in activities of public welfare or } \\
\text { community service. }\end{array}$ \\
\hline $\begin{array}{l}\text { Protecting and } \\
\text { Saving Company } \\
\text { Resources }\end{array}$ & $\begin{array}{l}\text { Includes actions that save company resource, use personal resource to } \\
\text { aid the company, and protect the company from disasters. }\end{array}$ \\
\hline $\begin{array}{l}\text { Keeping the } \\
\text { Workplace Clean }\end{array}$ & Keeping the workplace clean. \\
\hline $\begin{array}{l}\text { Interpersonal } \\
\text { Harmony }\end{array}$ & $\begin{array}{l}\text { Refers to employee actions aimed at facilitating and preserving } \\
\text { harmonious relations in the workplace. }\end{array}$ \\
\hline
\end{tabular}

\section{Collectivism and OCB}

As an economics system, collectivism means in which the production and distributions are owned and controlled by the people collectively. In moral stance, political philosophy or social intention that collectivism promotes non independence and Strong compliance of individual people, while agreeing with each person's choices by society or any other group or institution.

In a highly collectivist culture such as China, organizational members relate more readily to an in-group based on extended family, place of origin, or networks of other ties and interests, such as alma mater (Farh et al., 1998). History (China's history in particular) documents that collectivist cultures are driven with periodic spasms of large-scale, intense conflict between large factions; the tree-generational narrative Wild Swans (Chang 1991). Even instances of petty disagreement can, and often do, develop into bitter conflict at a major level between in-groups and out-groups, affecting not only organizational affairs, but also spilling over into the community. Escalation of conflict presents 
serious risks. Thus, in China we would likely find less inclination to consider as OCB those actions that challenge the status quo or stir up disagreement, we would probably see considerably more appreciation for spontaneous gestures that help preserve harmony and head off potential conflict.

Another implication of cultural collectivism has to do with the more personal forms of OCB. The above review leads us to expect that prevailing forms of OCB in China may be quite different from those described in the Western OCB literature. In a culture emphasizing more in-group versus out-group, we might not see helping as constrained to assistance in job operations. The coworker is also considered a friend, neighbor, comrade, and fellow community member. In China, OCB might well include assistance on a purely personal level, e.g., helping coworkers with family problems or ministering to them when they are ill.

\section{References}

[1]. Bienstock, C. C., DeMoranville, C. W. \& Smith, R. K, Organizational Citizenship Behavior and Service Quality, Journal of Services Marketing, 17 (4) (2003): 357-378.

[2]. Bolino, M. C. \& Turnley, W. H, "Going the Extra Miles: Cultivating and Managing Employee Citizenship Behavior". Academy of Management Executive, 17 (3) (2003):60-71.

[3]. Caligiuri, P. M. \& Day, D. V, Effects of Self-Monitoring on Technical, Contextual, and Assignment-Specific Performance: A Study of Cross-National Work Performance Ratings, Group and Organization Management,2000, 25 (2): 154-174.

[4].Farh, J. L., Earley, P. C. \& Lin, S. C, Impetus for Action: A Cultural Analysis of Justice and Organizational Citizenship Behavior in Chinese Society, Administrative Science Quarterly, 1997, 42 (3): 421-444.

[5] Farh, J., Zhong, C. \& Organ, D. W. Organizational Citizenship Behavior in the People?S Republic of China, Organization Science, 2004, 15 (2): 241-253.

[6] Kim, T. M., Lee, K. H. \& Cho, S. H, A Study on the Effects of Travel Agency Employee's Perceived Organizational Justice on Organizational Commitment and Organizational Citizenship Behavior, Korean Culture Tourism Studies, 2005, 7 (1): 155-186.

[7] Organ, D. W. \& Ryan, K, A Meta-Analytic Review of Attitudinal and Dispositional Predictors of Organizational Citizenship Behavior, Personnel Psychology, 1995, 48 (4): 775-802.

[8] Somech, A. D. A, Exploring Organizational Citizenship Behavior From an Organizational Perspective: The Relationship Between Organizational Learning and Organizational Citizenship Behavior, Journal of Occupational and Organizational Psychology, 2004, 77: 281-298.

[9] Pearson, M. M, Joint Ventures in the People's Republic of China. Princeton, NJ: Princeton University Press, 1991.

[10] Natasha A. Tassell, Ross A. Flett and Jhanitra R. Gavala. Individualism/Collectivism and Academic Self-Enhancement in New Zealand Māori University Students, Journal of Pacific Rim Psychology, 2010,4(2):138-151. 